\author{
Ada-Cristina MARINESCU, PhD \\ Institute for World Economy, Romanian Academy \\ E-mail: adacmarinescu@gmail.com \\ Geo-Alexandru SPANULESCU, PhD Candidate \\ Maria-Anca CRAIU, PhD Candidate \\ Ruxandra NOICA, PhD Candidate \\ Doctoral School of the Romanian Academy, SCOSAAR

\section{DETERMINANTS OF PUBLIC INVESTMENT IN EUROPEAN UNION COUNTRIES}

\begin{abstract}
We will try to investigate in this article which are the determinants of public investment in European Union countries. Investments have experienced a serious downward trend in the last three decades in EU, and this decreasing trend has become more pronounced after the economic crisis. Therefore we will analyze the main determinants of public investment in EU in order to discover which variables have a significant impact upon investment evolution. We will use panel data for EU countries during the period 1995-2017 and we will employ regression models in order to study the impact of economic and fiscal factors upon public investment. The result of our analysis shows that public investment is positively influenced by output gap, revenues and population change, while GDP growth rate, net lending, expenditure, gross debt, interest rate and active population have a negative impact upon investment. Fiscal policy decisions also play an important part in engaging public investment expenditure.

Key words: public investment, fiscal policy, macroeconomic determinants of gross fixed capital formation.

\section{JEL classification: E20, H54, R53}

Situation of public investment in European Union

The economic crisis has lead to a substantial decrease of public investment throughout the European Union. Gross fixed capital formation of the general government accounted for $2.83 \%$ of GDP in 2018 in EU, down from $3.21 \%$ during the period preceding the crisis. Figure 1 shows the evolution of public investment for EU countries during 2000-2018, with forecast data for 2019-2020, witnessing a visible downward trend after 2008 .
\end{abstract}

DOI: 10.24818/18423264/53.4.19.02 
Ada-Cristina Marinescu, Geo-Alexandru Spanulescu, Maria-Anca Craiu, Ruxandra Noica

Figure 1. Public investment in the European Union, 2000-2020, \% of GDP

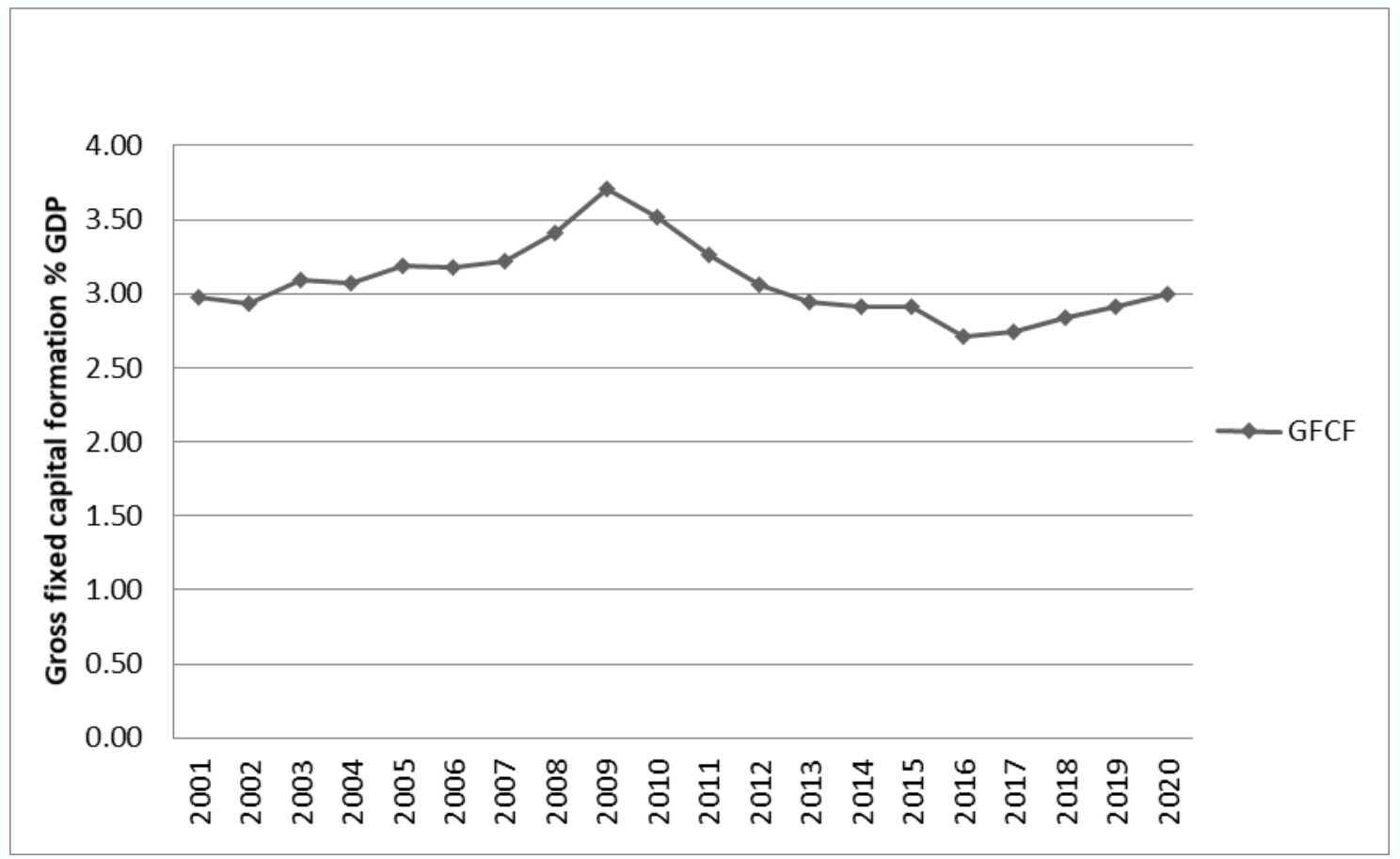

Source: Eurostat - AMECO

In figure 2 we have also represented the mean values of public investment during the period 1995-2017 for EU countries, depending both on country and year. The lowest mean values of public investment during this period were recorded in case of Belgium and Germany, while the biggest values were registered for Estonia and the Czech Republic. In general, new member states have a higher percentage of public investment because the capital stock is lower in these countries and there is an increased need for investment. 
Determinants of Public Investment in European Union Countries

Figure 2. Public investment - mean values by EU member state, 1995-2017

\section{Mean of GFCF by COUNTRY}

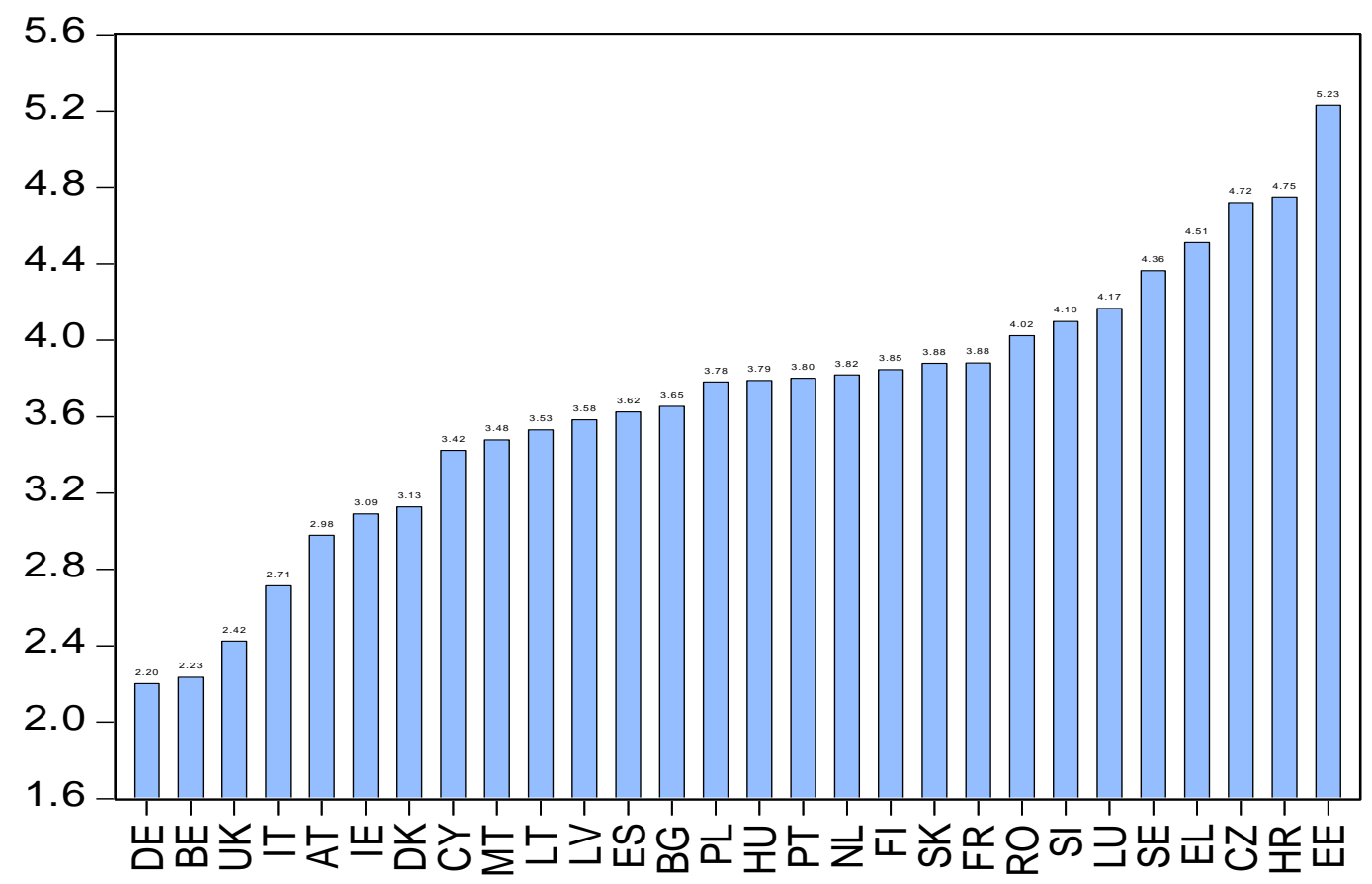

Source: Author`s calculations

If we analyze the situation of public investment in European Union by year, we can notice that 2016 and 2017 were the years with the lowest values for public investment, while during 2008 and 2009 public investment recorded the highest values during the period taken into consideration.

The decrease of public investment can be seen even more clearly in the countries most affected by the economic crisis. In countries such as Ireland, public investment amounted to $2.14 \%$ of GDP in 2018, more than a percent decrease from $3.50 \%$ in 2000 , while in the case of Greece public investment reached $3.50 \%$ of GDP in 2018 dropping from $5.05 \%$ in 2000.

Several explanations have been proposed for this substantial decrease in public investment in European Union. The implementation of public investment is motivated by political decisions to engage public expenditure, and periods of recession usually

DOI: 10.24818/18423264/53.4.19.02 


\section{Ada-Cristina Marinescu, Geo-Alexandru Spanulescu, Maria-Anca Craiu, Ruxandra Noica}

entail the cutting of public investment. On the other hand, public investment might have reached a critical limit, as several studies document a saturation of public capital stocks. Issues related to the productivity or efficiency of public investment are also tackled in the attempt to understand the process of engaging public investment.

The evolution of public investment can be also related to the evolution of private sector investment. An increase in public investment can have both crowding in and crowding out effects upon private investment. Public investment can have a crowding out effect upon private investment as an increase of public investment can contribute to the increase of deficits and in this situation private investment will be affected. An increase in public investment will require more funds for financing, which can be obtained by increasing the level of taxes or through borrowing from the capital markets, resulting eventually in an increase of the borrowing cost and of interest rates. In this case private investment will experience a decrease as well. On the other hand, public investment may contribute to economic growth and may produce also a rise in private investment due to productivity boost.

Public investment is closely related to the measures of fiscal consolidation. During the economic crisis, the European Union countries followed significant fiscal consolidation programs, and within these programs, the reduction of public investment was one of the measures most widely adopted. The pattern of fiscal consolidation usually implemented at EU level is applied through investment cuts -25 out of 32 lasting and significant budget consolidation episodes, which took place in the EU-15 between 1980 and 1997 were mostly obtained through investment cuts (Balassone and Franco, 2000).

At the political level, investment expenses are usually considered the most convenient category of budgetary expenditure which can be cut during crisis. This trend of reducing public investment during budgetary consolidation is followed extensively in all countries. Political decisions are short-term oriented and politicians usually prefer to cut investment expenses, which are not compulsory and whose effect is visible on long term, as compared with other categories of more urgent public expenditure.

Therefore, in order to protect public investment from being a disadvantaged category of expenses, several initiatives were proposed, including the introduction of a golden rule which would exclude public investment from the fiscal deficit rule. Thus, public investment can be financed by borrowing, while current governmental expenses should be financed from taxes. Such a measure could save public investment by allowing an unlimited financing for investment as long as the debt engaged for implementing public investment is backed up by the public capital stock thus created and future generations can benefit from the effect of these expenses. 


\section{Determinants of Public Investment in European Union Countries}

Borrowing for investment does not represent actually debt because it serves future generations and it is therefore natural for them to bear the cost of public investment from which they benefit.

Investment thus assumed will turn into public capital. The golden rule will contribute to the fact that the stock of public debt will be complemented by a similar stock of public capital. The golden rule proposes that no borrowing should be allowed except to finance the public investment so that debt will be matched by increases in the public capital stock.

The golden rule of public investment envisaged that public investment be excluded from the category of governmental expenses so that the deficit is not affected by this kind of expenses. Therefore, there is no explicit limit for public investment expenses, taking into account that investment has already decreased to very low levels in many EU countries.

The argument in favor of the golden rule is based on the idea that public investment is different from any other form of public expenditure. Public investment has the potential to improve long-term economic growth by increasing the capital stock.

\section{Literature review}

Several econometric models were used in the literature in order to study the factors which influence public investment. Most authors use panel data techniques in order to analyze the explicative factors for public investment, using several economic and fiscal variables among potential regressors.

De Haan et al. (1996) and Sturm (1998) use panel data for 22 OECD countries for the period 1980-1992 and they try to find economic and political determinants of public investment. The conclusion of their studies is that episodes of "fiscal stringency" and changes of government are correlated with lower rates of public investment.

Gali and Perotti (2003) analyze the determinants of public investment in European Monetary Union countries, with a special focus on whether or not EMU has changed the cyclical behaviour of public investment. The explanatory variables used are the expected output gap and public debt. The behaviour of public investment is found to be "mildly procyclical". EMU has reportedly not caused any statistically significant change in this relationship.

Starting from the observation that public investment has already decreased to very low levels in many EU countries, Blanchard and Giavazzi (2004) propose to modify the Stability and Growth Pact in order to exclude public investment from the fiscal deficit rule, allowing public investment to be financed out of net borrowing, 


\section{Ada-Cristina Marinescu, Geo-Alexandru Spanulescu, Maria-Anca Craiu,}

Ruxandra Noica

unlike current expenses. The deficit rule would thus refer only to the current account balance.

In a study of the European Commission (2003) a panel data analysis of the determinants of public investment in the European Union shows that European Monetary Union has had a positive direct impact on the level of public investment, but a negative indirect impact through a reduction in fiscal deficits and public debt. The explicative variables used for this analysis are real per capita GDP, output gap, real long-term interest rates, cyclically adjusted budget balance, public debt, total revenue or current expenditure of the general government and an EMU dummy. The conclusion of this study is that public investment in percent of GDP tends to decline with GDP growth in real per capita terms, with a deterioration in the cyclically adjusted budget balance and with increasing public debt.

Turrini (2004) analyzed the factors which influence public investment in the European Union using panel data regressions. The regressors include several economic variables such as trend GDP, output gap, real long-term interest rates, cyclically adjusted budget balance, public debt, total revenue or current expenditure of the general government and also an EMU dummy. The conclusion of the study is that GDP growth in per capita trend GDP has a negative influence upon public investment, which decreases with GDP growth. At the same time, public investment decreases with a deterioration in the cyclically adjusted primary balance and with increasing public debt. The study shows that European Monetary Union has had a significant impact on public investment.

Mehrotra and Välilä (2005) estimate panel data and cointegration models for old EU member states for the period 1970-2003 in order to establish the determinants of public investment. The result of the study is that public investment is influenced by national income, the stance of budgetary policies, and fiscal sustainability considerations. The authors do no find any significant effect of EMU rules upon public investment. Rather public investment seems to be affected by episodes of fiscal consolidation.

In the panel data analyses the gross fixed capital formation of the general government is regressed on various measures of real output, real long-term interest rates, public debt, net lending (overall surplus) of the general government and on a dummy variable to account for the participation of the respective economy in EMU. In the cointegration analysis the authors try to identify common stochastic trends among public investment, budgetary position and public debt.

The study shows that output is a statistically significant explanatory variable, with a positive coefficient and that public investment tends to move in tandem with discretionary changes in fiscal policy. The net lending variable has a significant and 


\section{Determinants of Public Investment in European Union Countries}

negative coefficient, so fiscal consolidation influences negatively public investment, while public investment has increased during episodes of discretionary fiscal expansion. The debt variable is always significant and negative.

Other authors (Albu, 2010) study the effect of public investment on economic growth in European Union countries. The study shows that GDP growth rate is higher for smaller values of interest rate and respectively for higher values of investment ratio. Contrary, smaller growth rate corresponds to higher values of interest rate and respectively to smaller values of investment rate.

\section{Determinants of public investment in EU member states}

There is a broad range of factors which influence the dynamics of public investment, starting from economic variables to fiscal factors as well as political constraints. Economic factors include GDP per capita, as countries with higher rates of GDP per capita tend to invest more. The fiscal position of a country is also an important variable, because countries experiencing high debt or deficit will find it difficult to find resources for investment and will undergo episodes of fiscal consolidation. Public debt is also an important variable which affects public investment, because it influences the realization of new investments. Interest rate is also a variable which has an impact upon public investment, because the cost of capital determines the decision to invest. The reason for including the deficit variable is that an increasing deficit will entail an increased probability for fiscal consolidations in order to reduce deficits, which will imply a reduction in public investment (Oxley and Martin, 1991).

The macroeconomic factors which influence public investment try to capture the effect of cyclical factors upon spending on public investment. These cyclical factors include the rate of inflation, the rate of unemployment or the growth rate of real GDP (Turini, 2004).

According to some authors, public investment is procyclical, typically boosted in periods of high growth and depressed during episodes of recession (Mehrotra and Välilä, 2006).

At the same time, the actual level of public investment is influenced by past investment and by the actual level of capital stock. Already high levels of capital stock and public investment can affect the new investment decisions (Heineman, 2006).

Foreign direct investments also influence the behavior of public investment in a negative way (Heinemann, 2006). The explanation results from ensuring lower taxes for private investment rather than quality of infrastructure.

The fiscal policy rules play an important part in the decline of public investment in European Union countries. The convergence criteria from the Treaty of 


\section{Ada-Cristina Marinescu, Geo-Alexandru Spanulescu, Maria-Anca Craiu,} Ruxandra Noica

Maastricht referring to public debt and deficits and also the fiscal rules within the Stability and Growth Pact include clear limits for public debt and deficits and thus have an impact on the evolution of public investment. In periods of fiscal consolidation, governments usually resort to investment cuts. Investments decreases is the most attractive solution on short term and these phenomenon can be seen in the European Union as a result of the measures taken after the economic crisis.

Public debt is one of the variables which have a negative impact on public investment. In general, high debt countries and especially risks for public debt sustainability are found to affect in a negative manner the evolution of public investment. Governments which have high levels of public debt or are in a difficult borrowing situation will undertake less public investment.

\section{Empirical model of the determinants of public investment}

We will use in this paper panel data models in order to investigate the relationship between public investment and several economic variables which are likely to affect the evolution of public investment. We will use data for EU28 in the period 1995-2017, taken from AMECO and EUROSTAT databases.

Our model is the following equation of regression in order to study the effect of the independent variables such as growth rate of GDP, output gap, net lending (borrowing), total government revenues, total government expenditure, public debt, interest rate, active population, population change on public investment. We will use for our analysis panel data regression, with country-fixed and time-fixed effects.

$$
\begin{aligned}
& \text { gfcf }_{i t}= \\
& \propto+\beta_{1} \text { grow }_{\text {rat }_{i, t-1}}+\beta_{2} \text { output }_{i, t-1} \\
& +\beta_{3} \text { net }_{\text {lend }_{i, t-1}+\beta_{4} \text { reven }_{i, t-1}+\beta_{5} \text { expend }_{i, t-1}+\beta_{6} \text { debt }_{i, t-1}+\beta_{7} \text { int }_{i, t-1}+\beta_{8} \text { activepop }_{i, t-1}} \\
& +\beta_{9} \text { popchang }_{i, t-1}+\gamma_{i}+\theta_{t}+\epsilon_{i t}
\end{aligned}
$$

The dependent variable gross fixed capital formation ( $\mathrm{gfcf}$ ) is expressed as the ratio of gross fixed capital formation to GDP.

In line with the literature, we will use several fiscal variables which are strongly related with public investment. The group of fiscal variables includes the revenues and expenditure of the general government, public debt, interest rate and net lending (borrowing), expressed as a percentage of GDP.

The other variables include growth rate of GDP per capita, output gap as a percentage of GDP, the active population and total population change, expressed in percentages.

DOI: $10.24818 / 18423264 / 53.4 .19 .02$ 


\section{Determinants of Public Investment in European Union Countries}

All these variables are included with a lag of one year, because the effect of these variables is usually manifest after a period of one year. We will also include specific effects (fixed or random) for cross-sectional units (countries) and for time periods.

The expected coefficients of the analyzed variables are presented next:

- $\quad$ Total revenue is expected to have a positive impact upon public investment, as greater governmental funds will entail bigger investment expenses $(+)$.

- Total expenditure is expected to affect in a negative manner public investment

$(-)$.

- Output gap is estimated to have a positive impact on public investment: a greater GDP will imply increased public investment (+).

- $\quad$ Public debt will have a negative effect upon public investment: a bigger value of public debt will determine governments to realize fewer public investments (-).

- $\quad$ The interest rate as a percentage of GDP will have a negative effect upon public investment (-): financial conditions affect the evolution of public investment, in case of increased interest rates, the country will have less access to finance for public investments.

- Net lending (borrowing) is expected to have a negative sign upon public investment (-).

- $\quad$ Growth rate of GDP will have a positive effect on public investment (+): an increase of GDP growth rate will contribute to a rise in public investment.

- $\quad$ Total active population will have a positive effect on public investment (+).

- $\quad$ Population change will also impact positively on public investment $(+)$.

We will apply this model for analyzing all countries within EU28 as a group.

Table 1 shows the results obtained from analyzing the main variables from the model.

Table 1: Descriptive statistics

\begin{tabular}{|l|l|l|l|l|ll|}
\hline Variable & Average & $\begin{array}{l}\text { Standard } \\
\text { deviation }\end{array}$ & Maximum & Minimum & Jarque-Bera test & \\
\hline $\begin{array}{l}\text { Gross fixed } \\
\text { capital } \\
\text { formation }\end{array}$ & 3.66 & 1.07 & 7.72 & 0.54 & $\begin{array}{l}\text { Jarque-Bera } \\
\text { (Probability }\end{array}$ & $\begin{array}{l}12.93 \\
0.00)\end{array}$ \\
\hline $\begin{array}{l}\text { Total } \\
\text { revenue }\end{array}$ & 42.33 & 6.45 & 58.28 & 24.24 & $\begin{array}{l}\text { Jarque-Bera } \\
\text { (Probability }\end{array}$ & $\begin{array}{l}8.48 \\
0.01)\end{array}$ \\
\hline $\begin{array}{l}\text { Total } \\
\text { expenditure }\end{array}$ & 44.73 & 6.66 & 65.04 & 24.00 & $\begin{array}{l}\text { Jarque-Bera } \\
\text { (Probability }\end{array}$ & $\begin{array}{l}2.72 \\
0.25)\end{array}$ \\
\hline Output gap & -0.17 & 3.19 & 16.86 & -15.80 & $\begin{array}{l}\text { Jarque-Bera } \\
\text { (Probability }\end{array}$ & $\begin{array}{l}638.83 \\
0.00)\end{array}$ \\
\hline
\end{tabular}

DOI: 10.24818/18423264/53.4.19.02 
Ada-Cristina Marinescu, Geo-Alexandru Spanulescu, Maria-Anca Craiu, Ruxandra Noica

\begin{tabular}{|c|c|c|c|c|c|c|}
\hline Public debt & "57.18 & 33.31 & 18182.54 & "3.66 & $\begin{array}{l}\text { Jarque-Bera } \\
\text { (Probability }\end{array}$ & $\begin{array}{l}114.79 \\
0.00)\end{array}$ \\
\hline $\begin{array}{l}\text { The interest } \\
\text { rate }\end{array}$ & 2.54 & 1.80 & 15.82 & 0.035 & $\begin{array}{l}\text { Jarque-Bera } \\
\text { (Probability }\end{array}$ & $\begin{array}{l}1777.6 \\
0.00)\end{array}$ \\
\hline $\begin{array}{l}\text { Net lending } \\
\text { (borrowing) }\end{array}$ & -2.39 & 3.37 & 6.85 & -32.02 & $\begin{array}{l}\text { Jarque-Bera } \\
\text { (Probability }\end{array}$ & $\begin{array}{l}2376.83 \\
0.00)\end{array}$ \\
\hline $\begin{array}{l}\text { Active } \\
\text { population }\end{array}$ & 69.94 & 5.46 & 82.50 & 57.50 & $\begin{array}{l}\text { JarqueBera } \\
\text { (Probability }\end{array}$ & $\begin{array}{l}8.08 \\
0.01)\end{array}$ \\
\hline $\begin{array}{l}\text { GDP growth } \\
\text { rate }\end{array}$ & 2.67 & 3.42 & 25.56 & -14.81 & $\begin{array}{l}\text { Jarque-Bera } \\
\text { (Probability }\end{array}$ & $\begin{array}{l}1026.0 \\
0.00)\end{array}$ \\
\hline $\begin{array}{l}\text { Population } \\
\text { change }\end{array}$ & 2.07 & 8.16 & 32.90 & -35.00 & $\begin{array}{l}\text { Jarque-Bera } \\
\text { (Probability }\end{array}$ & $\begin{array}{l}122.10 \\
0.00)\end{array}$ \\
\hline
\end{tabular}

Source: Author`s calculations

As regards the properties of our sample data, unit root single series tests indicate that our variables are not stationary, thus warranting the inclusion of firstorder differences of the explanatory variables. Jarque-Bera test for a normal distribution shows that variables are not normally distributed with the exception of total revenues and total expenditure.

We perform also panel based unit root tests to verify the stationarity properties of our variables. Panel based unit root tests have been proposed recently by authors such as Levin, Lin and Chu (2002) and Im, Pesaran and Chin (2003). These tests have been built in analogy with unit root single series tests. According to these authors, panel unit root tests are more adequate because they are less likely to commit a type II error than single series tests because time series and cross-section data information complement each other. All panel unit root tests assume that there is a common unit root process across cross-sections.

We will continue by presenting in figure 4 the correlations between the variables included in the model. Gross fixed capital formation has a negative, but insignificant correlation with active population, expenditure, net lending, population change, revenue and a negative correlation, though more significant, with debt and interest. The variables output gap and growth rate of GDP are positively correlated with gross fixed capital formation (table 2). 
Determinants of Public Investment in European Union Countries

Table 2: Correlations between variables

\begin{tabular}{|c|c|c|c|c|c|c|c|c|c|c|}
\hline & $\begin{array}{l}\text { Active } \\
\text { population }\end{array}$ & $\begin{array}{l}\text { Public } \\
\text { debt }\end{array}$ & $\begin{array}{l}\text { Government } \\
\text { expenditures }\end{array}$ & \begin{tabular}{|l} 
GDP \\
growth \\
rate
\end{tabular} & $\begin{array}{l}\text { Gross } \\
\text { fixed } \\
\text { capital } \\
\text { formation }\end{array}$ & $\begin{array}{l}\text { Interest } \\
\text { rate }\end{array}$ & $\begin{array}{l}\text { Net } \\
\text { lending } \\
\text { (surplus) }\end{array}$ & $\begin{array}{l}\text { Output } \\
\text { gap }\end{array}$ & $\begin{array}{l}\text { Population } \\
\text { change }\end{array}$ & $\begin{array}{l}\text { Govern } \\
\text { ment } \\
\text { revenues }\end{array}$ \\
\hline $\begin{array}{l}\text { Active } \\
\text { population }\end{array}$ & 1.00 & & & & & & & & & \\
\hline Public debt & $-0.16^{*}$ & 1.00 & & & & & & & & \\
\hline $\begin{array}{l}\text { Government } \\
\text { expenditures }\end{array}$ & $0.11 *$ & $0.51 *$ & 1.00 & & & & & & & \\
\hline $\begin{array}{l}\text { GDP growth } \\
\text { rate }\end{array}$ & $-0.12 *$ & $-0.30 *$ & $-0.45^{*}$ & 1.00 & & & & & & \\
\hline $\begin{array}{l}\text { Gross fixed } \\
\text { capital } \\
\text { formation } \\
\end{array}$ & $-0.07 * * *$ & $-0.36^{*}$ & -0.04 & 0.02 & 1.00 & & & & & \\
\hline Interest rate & $-0.44 *$ & $0.72 *$ & $0.37 *$ & $-0.13 *$ & $-0.29^{*}$ & 1.00 & & & & \\
\hline $\begin{array}{l}\text { Net } \\
\text { lending } \\
\text { (surplus) } \\
\end{array}$ & $0.24 *$ & $-0.37 *$ & $-0.31 *$ & $0.36 *$ & $-0.08 * *$ & $-0.36^{*}$ & 1.00 & & & \\
\hline $\begin{array}{l}\text { Output } \\
\text { gap }\end{array}$ & -0.03 & $-0.34 *$ & $-0.32 *$ & $0.58 *$ & $0.16 *$ & $-0.13^{*}$ & $0.38 *$ & 1.00 & & \\
\hline $\begin{array}{l}\text { Population } \\
\text { change }\end{array}$ & $0.12 *$ & 0.04 & $0.07 * * *$ & 0.01 & -0.06 & -0.007 & $0.19 *$ & $0.17 *$ & 1.00 & \\
\hline $\begin{array}{l}\text { Government } \\
\text { revenues }\end{array}$ & $0.25^{*}$ & $0.31 *$ & $0.84 *$ & $-0.25 *$ & $-0.08 * *$ & $0.18 *$ & $0.23 *$ & $-0.11 *$ & $0.18 *$ & 1.00 \\
\hline
\end{tabular}

$*$ represents significance at $1 \%, * *$ significance at $5 \%$ and $* * *$ significance at $10 \%$.

Source: Author`s calculation

DOI: 10.24818/18423264/53.4.19.02 
Ada-Cristina Marinescu, Geo-Alexandru Spanulescu, Maria-Anca Craiu, Ruxandra Noica

We will estimate the equation using the results of the Hausman test which will establish the specification for model effects. The result of the Hausman test shows that it is preferable to use the fixed effects estimator. Also the likelihood test for the significance of fixed effects indicated the importance of cross-section and time-effects, and as a consequence we will have to use the two way fixed effects estimator (table 3).

Table 3: Estimation results, OLS panel fixed-effects

\begin{tabular}{|l|l|}
\hline Variable & Coefficient \\
\hline GDP_GROWTH & $-0.03^{*}$ \\
& $(-2.69)$ \\
\hline OUPUT_GAP & $0.08^{*}$ \\
& $(6.55)$ \\
\hline REVEN & $0.16^{* *}$ \\
& $(1.88)$ \\
\hline NET_LENDING & $-0.18^{* *}$ \\
& $(-2.22)$ \\
\hline DEBT & $-0.01^{*}$ \\
& $(-4.15)$ \\
\hline INTEREST & $-0.14^{*}$ \\
& $(-4.23)$ \\
\hline POP_CHANGE & $0.01^{* *}$ \\
& $(1.50)$ \\
\hline ACTIVE_POPULATION & $-0.02^{* * *}$ \\
& $(-1.88)$ \\
\hline R $^{2}$ & 0.60 \\
\hline Number of observations & 588 \\
\hline
\end{tabular}

t-statistic in parenthesis; *, ** and $* * *$ denote respectively statistical significance at 1,5 and $10 \%$.

Source: Author`s calculations

The probability values are situated below the 5\% threshold, therefore the parameters of the model are different from zero, with the exception of the independent variable expenditure, which is not statistically significant. The coefficient of variation 0.60 shows that $60 \%$ from the variation of the dependent variable is explained by the economic factors included in our analysis. 


\section{Determinants of Public Investment in European Union Countries}

None of the coefficients included in the model for determining the impact of economic and fiscal factors upon public investment obtained a very high level of significance.

Our results show that there is a negative correlation between public investment and rate of growth of GDP at the level of the European Union. An increase by $10 \%$ in GDP growth rate will entail a decrease in gross fixed capital formation by $-0.32 \%$.

Output gap obtained a positive statistically significant coefficient $(0.09 \%)$; an increase by $10 \%$ in output gap will produce an increase in gross fixed capital formation by $0.9 \%$. Revenues are also positively correlated with the variable gross fixed capital formation, with a coefficient of $0.16 \%$. An increase of revenues by $10 \%$ will therefore result in an increase of public investment by $1.6 \%$, which represents a significant outcome.

Net lending (borrowing) has a negative statistically significant coefficient (0.18 ). An increase of net lending by $10 \%$ will contribute to a subsequent decrease of investment by $1.8 \%$, which is explainable taking into account the importance of the budgetary position of the government when implementing public investment.

Debt obtained a negative coefficient, not very big although statistically significant (-0.01); an increase of debt by $10 \%$ will have as result a decrease of gross fixed capital formation by $0.1 \%$, which is not an important result. Therefore, it seems that debt does not have a major effect on public investment.

Interest is also negatively correlated with gross fixed capital formation, by $0.149 \%$. This result shows that an increase of the interest rates by $10 \%$ will produce a decrease by $1.49 \%$ of public investment, because financial conditions affect the decision for gross fixed capital expenditure.

Population change has a positive impact on investment expenditure, the coefficient is positive and statistically significant at $0.01 \%$. An increase of the rate of population change by $10 \%$ will contribute to an increase of public investment by $0.1 \%$. Our estimations show that active population has a negative and statistically significant coefficient of $-0.02 \%$.

\section{Conclusions}

We have tried to investigate in this article which are the main macroeconomic determinants for public investment. Starting from the evidence of an extremely low level of investment in the European Union due to the fact that most member states have been affected by the last economic crisis, we have studied the impact of several variables on gross fixed capital formation.

Public investment is a category of governmental expenses which is usually most hit by recessions, and cut during fiscal consolidation episodes. In order to find a 


\section{Ada-Cristina Marinescu, Geo-Alexandru Spanulescu, Maria-Anca Craiu,}

Ruxandra Noica

solution for ensuring public investment rates to return to pre-crisis levels, several solutions were proposed, including the enforcement of a golden rule. The golden rule would allow unlimited spending for investment financed on the base of borrowing, leaving all other current public expenses to be financed from taxes. Thus, the Stability and Growth Pact should be amended in a such a way to exclude public investment from the fiscal deficit rule. It is usually considered that the Maastricht Treaty and fiscal rules embodied in the EU treaties have not ensured a fair treatment for public investment expenses. One direction for further study should be if fiscal rules have indeed played a role in public investment evolution in the European Union.

On the other hand, there are many variables identified in the literature which are likely to impact on public investment. Authors usually distinguish between several categories of factors: economic, political and institutional variables, which can have an influence on public investment. We have concentrated in our study on several macroeconomic factors, such as the growth rate of real GDP, output gap, active population and the rate of change for the population. We have also included fiscal factors, like government expenses and revenues, net lending (borrowing), public debt and interest rate, all expressed as percentages of GDP.

The results of our panel data analysis applied in case of the whole group of EU countries show that revenues, output gap and population change are positively correlated with public investment. Revenues have a positive statistically significant coefficient of 0.16 , and these seem to have the highest significance among all variables used; an increase in public revenues by $1 \%$ is likely to result in an increase of gross fixed capital formation with $0.16 \%$. Output gap is statistically significant at $0.08 \%$, an increase of output gap by $1 \%$ will lead to an increase of public investment by $0.08 \%$, while in case of the population change - an increase of the rate of population change by $1 \%$ will produce an increase of investment by $0.01 \%$.

All the other variables included in our study have a negative impact on public investment. The study should be continued with trying to identify common trends between EU states divided in groups, while focusing on fiscal sustainability considerations. It would be worth studying which is the effect of the fiscal rules on public investment, because fiscal consolidation episodes and subsequent investment cuts were mostly a result of interventions in order to keep deficit and debt within sustainability limits. Investment reduction is one fiscal policy tool used during budgetary consolidations in order to satisfy debt sustainability concerns and therefore it should be studied in closer relation with public debt evolution in the European Union. 
Determinants of Public Investment in European Union Countries

\section{REFERENCES}

[1]Albu, L.-L. (2010), Scenarios for Post-crisis Period Based on a Set of Presumed Changes in the Interest Rate - Investment - GDP Growth Relationship; MPRA Paper 32753, University Library of Munich, Germany;

[2]Balassone F. and Franco D. (2000), Public Investment, the Stability Pact and the Golden Rule; Fiscal Studies, Vol. 21, No. 2, pp. 207-229;

[3]Blanchard, O. and Giavazzi, F.(2004), Improving the SGP through a Proper Accounting of Public Investment; CEPR Discussion Paper No. 4220;

[4]European Commission (2003), Public Finances in EMU; European Commission, Directorate-General for Economic and Financial Affairs Publication;

[5]Galí, J. and Perotti, R. (2003), Fiscal Policy and Monetary Integration in Europe; Economic Policy, October 2003, pp. 533-572;

[6]Heinemann, F. (2006), Factor Mobility, Government Debt and the Decline in Public Investment; International Economics and Economic Policy, 3(1), pp. 11-26; [7]Im Kyung S., Pesaran M. and Shin Y. (2003), Testing for Unit Roots in Heterogeneous Panels; Journal of Econometrics, Vol. 115, Issue 1, pp. 53-74; [8]Levin, A., Lin, Chien-Fu and Chia-Shang J. (2002), Unit Root Tests in Panel Data: Asymptotic and Finite-sample Properties; Journal of Econometrics, Elsevier, Vol. 108(1), pp. 1-24;

[9]Mehrotra, A. and Välilä, T. (2006), Public Investment in Europe: Evolution and Determinants in Perspective; Fiscal Studies, Vol. 27, No. 4, pp. 443-471;

[10]Oxley, H. and Martin, J.P.(1991), Controlling Government Spending and Deficits: Trends in the 1980s and Prospects for the 1990s; OECD Economic Studies No. 17, pp. 145-189;

[11]Sturm, J.-E., Kuper, G.H. and de Haan, J.(1998), Modelling Government Investment and Economic Growth on a Macro Level: A Review; in: Market Behaviour and Macroeconomic Modelling, by Brakman, S., van Ees, H. and Kuipers, S.K. (eds.), Macmillan Press, London, UK;

[12]Turrini, A.(2004), Public Investment and the EU Fiscal Framework; European Commission, Directorate-General for Economic and Financial Affairs; Economic Papers, 202.

DOI: 10.24818/18423264/53.4.19.02 
Ada-Cristina Marinescu, Geo-Alexandru Spanulescu, Maria-Anca Craiu, Ruxandra Noica

\section{Annexes:}

Regression results

Dependent Variable: GFCF

Method: Panel Least Squares

Date: 02/08/19 Time: 00:20

Sample: 19952017

Periods included: 23

Cross-sections included: 28

Total panel (unbalanced) observations: 588

\begin{tabular}{lllll}
\hline \hline & Coefficient & Std. Error & t-Statistic & Prob. \\
\hline \hline C & 3.164569 & 1.324532 & 2.389197 & 0.0172 \\
GDP_GROWTH & -0.032885 & 0.012195 & -2.696570 & 0.0072 \\
OUPUT_GAP & 0.089992 & 0.013724 & 6.557153 & 0.0000 \\
REVEN & 0.160343 & 0.084876 & 1.889150 & 0.0594 \\
EXPEND & -0.080671 & 0.083507 & -0.966049 & 0.3344 \\
NET_LENDING & -0.185308 & 0.083316 & -2.224150 & 0.0265 \\
DEBT & -0.011473 & 0.002759 & -4.158020 & 0.0000 \\
INTEREST & -0.148548 & 0.035081 & -4.234376 & 0.0000 \\
POP_CHANGE & 0.011578 & 0.007691 & 1.505477 & 0.1328 \\
ACTIVE_POPULATI & & & & \\
ON & -0.028556 & 0.015140 & -1.886112 & 0.0598 \\
\hline \hline & Effects Specification & & \\
\hline \hline Cross-section fixed (dummy variables) & & \\
\hline \hline R-squared & 0.603914 & Mean dependent var & 3.661848 \\
Adjusted R-squared & 0.578035 & S.D. dependent var & 1.087657 \\
S.E. of regression & 0.706529 & Akaike info criterion & 2.203954 \\
Sum squared resid & 275.0501 & Schwarz criterion & 2.479360 \\
Log likelihood & -610.9624 & Hannan-Quinn criter. & 2.311261 \\
F-statistic & 23.33645 & Durbin-Watson stat & 0.753299 \\
Prob(F-statistic) & 0.000000 & & \\
\hline \hline
\end{tabular}


Determinants of Public Investment in European Union Countries

Results of Hausman test

Correlated Random Effects - Hausman Test

Equation: Untitled

Test cross-section random effects

\begin{tabular}{llll}
\hline \hline Test Summary & $\begin{array}{l}\text { Chi-Sq. } \\
\text { Statistic }\end{array}$ & Chi-Sq. d.f. & Prob. \\
\hline \hline Cross-section random & 11.510292 & 9 & 0.2423 \\
\hline \hline
\end{tabular}

Cross-section random effects test comparisons:

\begin{tabular}{lllll} 
Variable & Fixed & Random & Var(Diff.) & Prob. \\
\hline \hline GDP_GROWTH & -0.032885 & -0.033248 & 0.000004 & 0.8489 \\
OUPUT_GAP & 0.089992 & 0.085963 & 0.000010 & 0.2122 \\
REVEN & 0.160343 & 0.138168 & 0.000118 & 0.0411 \\
EXPEND & -0.080671 & -0.079885 & 0.000019 & 0.8550 \\
NET_LENDING & -0.185308 & -0.181301 & 0.000022 & 0.3956 \\
DEBT & -0.011473 & -0.011175 & 0.000002 & 0.8373 \\
INTEREST & -0.148548 & -0.162355 & 0.000079 & 0.1196 \\
POP_CHANGE & 0.011578 & 0.008251 & 0.000012 & 0.3428 \\
ACTIVE_POPULATI & & & & \\
ON & -0.028556 & -0.034149 & 0.000054 & 0.4482 \\
\hline \hline
\end{tabular}

Cross-section random effects test equation:

Dependent Variable: GFCF

Method: Panel Least Squares

Date: 02/08/19 Time: 00:15

Sample: 19952017

Periods included: 23

Cross-sections included: 28

Total panel (unbalanced) observations: 588

Coefficient Std. Error t-Statistic Prob.


Ada-Cristina Marinescu, Geo-Alexandru Spanulescu, Maria-Anca Craiu, Ruxandra Noica

\begin{tabular}{|c|c|c|c|c|}
\hline $\mathrm{C}$ & 3.164569 & 1.324532 & 2.389197 & 0.0172 \\
\hline GDP_GROWTH & -0.032885 & 0.012195 & -2.696570 & 0.0072 \\
\hline OUPUT_GAP & 0.089992 & 0.013724 & 6.557153 & 0.0000 \\
\hline REVEN & 0.160343 & 0.084876 & 1.889150 & 0.0594 \\
\hline EXPEND & -0.080671 & 0.083507 & -0.966049 & 0.3344 \\
\hline NET_LENDING & -0.185308 & 0.083316 & -2.224150 & 0.0265 \\
\hline DEBT & -0.011473 & 0.002759 & -4.158020 & 0.0000 \\
\hline INTEREST & -0.148548 & 0.035081 & -4.234376 & 0.0000 \\
\hline POP_CHANGE & 0.011578 & 0.007691 & 1.505477 & 0.1328 \\
\hline ACTIVE_POPULATI & & & & \\
\hline ON & -0.028556 & 0.015140 & -1.886112 & 0.0598 \\
\hline \multicolumn{5}{|c|}{ Effects Specification } \\
\hline \multicolumn{5}{|c|}{ Cross-section fixed (dummy variables) } \\
\hline R-squared & 0.603914 & \multirow{7}{*}{\multicolumn{2}{|c|}{$\begin{array}{l}\text { Mean dependent var } \\
\text { S.D. dependent var } \\
\text { Akaike info criterion } \\
\text { Schwarz criterion } \\
\text { Hannan-Quinn criter. } \\
\text { Durbin-Watson stat }\end{array}$}} & 3.661848 \\
\hline Adjusted R-squared & 0.578035 & & & 1.087657 \\
\hline S.E. of regression & 0.706529 & & & 2.203954 \\
\hline Sum squared resid & 275.0501 & & & 2.479360 \\
\hline Log likelihood & -610.9624 & & & 2.311261 \\
\hline F-statistic & 23.33645 & & & 0.753299 \\
\hline $\operatorname{Prob}($ F-statistic) & 0.000000 & & & \\
\hline
\end{tabular}

